\title{
Association between socioeconomic status and the prevalence of intestinal worm infection in primary school children
}

\author{
Sri Alemina Ginting, MD; Isra Firmansyah, MD; Dedi Satria Putra, MD; Dachrul Aldy, MD; \\ Syahril Pasaribu, MD; Chairuddin P Lubis, MD
}

\begin{abstract}
Background In Indonesia, medical problems are indicated by diseases associated with low socioeconomic status. The prevalence of intestinal worm is still high in Indonesia.

Objective The purpose of this study was to find the association between socioeconomic status and the prevalence of intestinal worm infection.

Methods A cross sectional study was done on 120 primary school children in Suka Village, Karo District, North Sumatra Province. Subjects were selected by means of random sampling. Kato Katz method was used in stool examination. Socioeconomic status was referred from the Survey Keluarga Sejahtera (Wealth Family Survey) 1998 by the BKKBN (the National Coordination Board on Family Planning). Data of socioeconomic status were collected by interview using a questionnaire and analyzed by chi square test; $p$ value of $<0.05$ was considered to be statistically significant.

Results Eighty-four subjects (70\%) suffered from intestinal worm infection. There was no significant association between either age $(p=0.811)$ or nutritional status $(p=0.792)$ and intestinal worm infection, but there was significant association between sex and intestinal worm infection $(p=0.028)$. There was also association between intestinal worm infection and father's education $(p=0.044)$. Mother's occupation had a significant association with intestinal worm infection $(p=0.001)$, but father's occupation $(p=0.474)$ did not. Neither parents' income $(p=0.429)$ nor socioeconomic status $(p=0.098)$ was associated with intestinal worm infection.

Conclusion There was significant association between intestinal worm infection and sex, father's education or mother's occupation [Paediatr Indones 2004;44:106-110].
\end{abstract}

Keywords: intestinal worm infection, socioeconomic status, primary school children

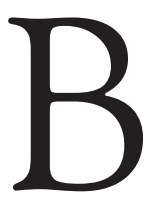
ased on the family census conducted in 1995 , it is gained that approximately 39.4 million (56\%) families in Indonesia are still in a poor life level. The family is called pra sejahtera and sejahtera I. These families are only able to meet their primary and basic needs such as food, clothes, house and health., ${ }^{1,2}$ The Gross National Product (GNP) of Indonesia in year 2000 was US \$.709. This amount is increased compared to that in 1999's (US \$ 621) and 1998's (US \$ 477), but it is still lower than the GNP prior to the economic crisis in 1997 (US \$1063) and in 1996 (US \$ 1124). . $^{3}$

In Indonesia, medical problems are indicated by diseases that are associated with low socio economic status. Intestinal worm infection is still high in Indonesia. It is understood because Indonesia is a developing country with low socioeconomic status, knowledge, environmental and personal hygiene. This can support the spread and infection of worms. The high-

From the Department of Child Health, Medical School, University of North Sumatera, Medan, Indonesia

Request reprints to: Dr. Sri Alemina Ginting, Department of Child Health, Adam Malik Hospital, Jalan Bunga Lau No.17 Medan 20136,Phone. 061- 8361721, Facs. 061- 8361721

Presented at the International Seminar on Parasitology and the $9^{\text {th }}$ Congress of the Indonesian Parasitic Disease Control Association, Bogor, 11. 12 September 2002 
est prevalence and intensity were found in primary school children. In North Sumatera, the prevalence of $57-90 \%$ in 1995 was found in Suka village which is located at 1400 meter above sea level with temperatures between $18-22^{\circ} \mathrm{C}$ and humidity of $70 \% .^{4}$ The number of primary school children infected was relatively high (648 persons). The population was 3821 people. Many with low income are predicted to be highly infected by intestinal worms. The aim of this study was to determine the prevalence of intestinal worm infection in primary school children and its association with socioeconomic status and other factors such as age, gender, parents' education and parents' occupation.

\section{Methods}

This cross sectional study was conducted at five primary schools in Suka village, Karo district, North Sumatera Province. Inclusion criteria were primary school children whose stool was examined. Exclusion criteria were children whose parents refused to follow this research. The calculated sample size was 120 subjects which were selected by simple random sampling. Data were taken by interview based on a closed questionnaire and observation to know the real condition and environment of the study location. Stool examination was done by collecting stool in a plastic bottle which was then examined by Kato Katz method. Intestinal worm infection was defined by finding worm eggs in the stool. ${ }^{4}$

Based on Badan Koordinasi Keluarga Berencana Nasional (the National Coordination Board on Family
Planning), the stage of family welfare are: ${ }^{1}$

1. Pre-prosperous family, defined as a family whose income cannot meet the minimum basic needs, such as spiritual needs, food, clothes, housing and health.

2. Prosperous level I family, defined as a family whose income can meet the minimum basic needs, but cannot meet the sociophysi-cologycal needs, such as education, family planning, family interaction, environmental interaction and transportation.

3. Prosperous level II family, defined as a family whose income can meet the basic needs and sociophysicologycal needs but cannot meet the developmental needs such as investations and information.

4. Properous level III family, defined as a family whose income can meet every need but has no money left for social activities.

5. Propserous level III plus family, defined as a family whose income can meet every need and can give money for people and take part in social activities.

Nutritional status was classified by using weight for age (W/A) parameters according to "Semiloka Anthropometri" based on WHO-NCHS standard, ${ }^{5}$ good nutrition: W/A between $-1 \mathrm{SD}$ and $+1 \mathrm{SD}$, moderate nutrition: W/A $>-2 \mathrm{SD}$ up to $<-1 \mathrm{SD}$, poor nutrition: W/A $>-3$ SD up to $<-2$ SD, bad nutrition: W/A $<-3$ SD.

Statistical analysis was applied to prove the relationship between two qualitative variables by using Chi square test; $p$ value of $<0.05$ was considered to be statistically significant.

Table 1. Sample characteristics

\begin{tabular}{|c|c|c|c|c|}
\hline \multicolumn{2}{|c|}{ Characteristic } & \multicolumn{2}{|c|}{ Intestinal worm infection } & \multirow[b]{2}{*}{$p$} \\
\hline & & $\begin{array}{l}\text { positive (84) } \\
\mathrm{n}\end{array}$ & $\begin{array}{l}\text { negative (36) } \\
\mathrm{n}\end{array}$ & \\
\hline \multirow[t]{2}{*}{ Age } & $: 6-9$ years & 44 & 18 & 0.811 \\
\hline & $10-13$ years & 40 & 18 & \\
\hline \multirow[t]{2}{*}{ Sex } & male & 51 & 14 & 0.028 \\
\hline & female & 22 & 33 & \\
\hline \multirow[t]{4}{*}{ Nutrition } & good & 39 & 19 & 0.792 \\
\hline & moderate & 33 & 13 & \\
\hline & mild malnutrition & 12 & 4 & \\
\hline & severe malnutrition & 0 & 0 & \\
\hline
\end{tabular}




\section{Results}

Eighty-four subjects were infected by intestinal worms. There was no significant association between age $(\mathrm{p}=0.811)$ or nutritional status $(\mathrm{p}=0.792)$ and intestinal worm infection but there was significant association between sex and intestinal worm infection $(\mathrm{p}=0.028)$ (see Table 1$)$.

Statistical analysis showed that father's education had significant association with the prevalence of intestinal worm infection $(\mathrm{p}=0.044)$ but mother's education did not $(p=0.061)$. Father's occupation had no significant association with evidence of intestinal worm infection $(p=0.474)$ but mother's occupation had $(p=0.001)$ (see Table 2).

Statistical analysis shows that neither parents' income nor socioeconomic status had significant association with intestinal worm infection $(\mathrm{p}=0.429$ and 0.098, respectively) (see Tables 3 and 4).

\section{Discussion}

One hundred and twenty children were examined, of whom $84(70 \%)$ suffered from intestinal worm infection. The result was the same with the prevalence of intestinal worm infection in North Sumatera and Indonesia. ${ }^{4}$

Ismid et al found the prevalence of Ascaris lumbricoides was $66.7 \%$, hook worm $14.74 \%$ and Trichuris trichiura 39.92\% in Madrasah Ibtidaiyah pupils in Cilungkup Village, East Jakarta. In Jembatan Besi, a poor village with a population of 63573 people $/ \mathrm{km}^{2}$ and low hygiene, the transmission of Ascaris lumbricoides was extensive. In this village the prevalence of intestinal worm infection was $95 \%{ }^{6}$ Noerhajati described the prevalence of Ascaris lumbricoides in Bantul primary school children was $76.4 \%$. Only few recorded about clinical cases. It is caused by the variation of clinical symptoms, which includes mild gastrointestinal symptoms and acute manifestation that requires hospitalization. Severe infection in children can cause malnutrition and growth disturbance. ${ }^{?}$

In this study we could not find association between age and intestinal worm infection. In Ampana Kota district, Central Sulawesi, Poespoprodjo described that children with intestinal worm infection were older than children without infection. ${ }^{8}$ Yared Merid et al described that intestinal worm infection was more frequently found in

Table 2. Parents' characteristics

\begin{tabular}{|c|c|c|c|}
\hline \multirow[t]{2}{*}{ Characteristic } & \multicolumn{2}{|c|}{ intestinal worm infection } & \multirow[b]{2}{*}{$\mathbf{p}$} \\
\hline & $\begin{array}{l}\text { positive (84) } \\
n\end{array}$ & $\underset{n}{\operatorname{negative}}(36)$ & \\
\hline \multicolumn{4}{|l|}{ Father education } \\
\hline Primary school & 31 & 11 & 0.044 \\
\hline Elementary school & 26 & 9 & \\
\hline High school & 25 & 10 & \\
\hline \multicolumn{4}{|l|}{ Characteristic } \\
\hline Academy & 0 & 3 & \\
\hline University Graduate & 2 & 3 & \\
\hline \multicolumn{4}{|l|}{ Mother education } \\
\hline Primary school & 35 & 11 & \\
\hline Elementary school & 21 & 5 & \\
\hline High school & 26 & 16 & 0.061 \\
\hline Academic & 2 & 2 & \\
\hline University Graduate & 0 & 2 & \\
\hline \multicolumn{4}{|l|}{ Father occupation } \\
\hline Farmer & 72 & 29 & \\
\hline Entrepreneur & 2 & 2 & 0.474 \\
\hline Employee & 5 & 5 & \\
\hline Others & 1 & 0 & \\
\hline \multicolumn{4}{|l|}{ Mother occupation } \\
\hline Farmer & 78 & 26 & \\
\hline Entrepreneur & 4 & 2 & 0.001 \\
\hline Employee & 2 & 8 & \\
\hline Others & 0 & 0 & \\
\hline
\end{tabular}


Sri Alemina Ginting et al: Association between socioeconomic status and the prevalence of intestinal worm infection

Table 3. Correlation betWeen PARENTS' income AND INTESTINAL WORM INFECTION

\begin{tabular}{lccc}
\hline Income & \multicolumn{2}{c}{ Intestinal worm infection } & p \\
\cline { 2 - 3 } & positive (84) & negative (36) & \\
\cline { 2 - 3 } & $\mathbf{n}$ & $\mathbf{n}$ & \\
\hline$<\operatorname{Rp~300.000}$ & 5 & 0 & \\
$\operatorname{Rp~301.000-Rp~400.000~}$ & 8 & 5 & \\
$\operatorname{Rp~401.000-Rp~500.000~}$ & 8 & 3 & \\
$\operatorname{Rp~501.000-Rp~600.000~}$ & 23 & 8 & \\
$\operatorname{Rp~601.000-Rp~700.000~}$ & 12 & 3 & \\
$>\operatorname{Rp~701.000}$ & 28 & 17 & \\
\hline
\end{tabular}

Table 4. Correlation between socioeconomic status AND INTESTINAL WORM INFECTION

\begin{tabular}{lccc}
\hline Socioeconomic status & \multicolumn{2}{l}{ Intestinal worm infection } & $\mathbf{p}$ \\
\cline { 2 - 3 } & positive (84) negative (36) & \\
\cline { 2 - 3 } & $\mathbf{n}$ & $\mathbf{n}$ & \\
\hline Pra sejahtera & 9 & 3 & \\
Sejahtera I & 39 & 10 & 0.098 \\
Sejahtera II & 26 & 13 & \\
Sejahtera III & 10 & 10 & \\
Sejahtera III plus & 0 & 0 & \\
\hline
\end{tabular}

children because they have more contact with source of infection and are more susceptible than adults. ${ }^{9}$ Abdul Rahman in Penang Malaysia described that there was no significant association between age and intestinal worm infection. ${ }^{10}$ The research of native people in Malaysia found that the prevalence and intensity of ascariasis and trichuriasis infection was highest at age $1-5$ year. ${ }^{11}$

We found association between sex and the prevalence of intestinal worm infection, but other investigators did not, which indicated that there was no behavioral difference between girls and boys. ${ }^{10.11}$ We could not find any association between nutritional status and intestinal worm infection. This was similar to the results of other studies. ${ }^{6,8}$

We could find significant association between father's education and intestinal worm infection, but no association between mother's education and intestinal worm infection. De Silva described mother's education was associated with the prevalence of intestinal worm infection, but father's education was not. ${ }^{14}$ Poespoprodjo described father's education had no association with the prevalence of intestinal worm infection. ${ }^{8}$ In Malaysia, parents' education was associated with the prevalence of intestinal worm infection in primary school children. ${ }^{12}$
We found that mother's occupation was related to the prevalence of intestinal worm infection, but father's occupation was not. This showed a great deal of mother's activities in taking care of her child. There was no association between socioeconomic status and the prevalence of intestinal worm infection in this region. In Ethiopia, the low socioeconomic status and bad sanitation were the cause of intestinal worm infection, and intestinal worm infection was the most common disease after malaria. ${ }^{13}$ Abdul Rahman, De Silva and also Compton and Savioli found that high transmission of intestinal worm infection from soil to human depended on socioeconomic factors such as density of population, illiteracy, bad sanitation and some behavior that is connected with culture. ${ }^{12,13}$

From this study we concluded that there was significant correlation between intestinal worm infection and father's education, mother's occupation, but not with mother's education, father's occupation, parents' income and socioeconomic status.

\section{References}

1. BKKBN. Panduan pembangunan keluarga sejahtera dalam rangka penanggulangan kemiskinan. Jakarta: Kantor Menteri Negara Kependudukan/BKKBN; 1997.

2. BKKBN. Petunjuk teknis pendataan dan pemetaan keluarga sejahtera: BKKBN, gerakan keluarga berencana nasional. 1 ${ }^{\text {st }}$ ed. Jakarta: BKKBN; 1993.

3. Departemen Kesehatan Republik Indonesia. Profil kesehatan Indonesia 2000. Jakarta: Departemen Kesehatan RI; 2001.

4. Siregar M. Penatalaksanaan program pemberantasan kecacingan di Dati II Propinsi Sumatera Utara (laporan). Medan; Kanwil Departemen Kesehatan RI, Propinsi Sumatera Utara; 1996.

5. WHO. Measuring change in nutritional status. Guidelines for assessing the nutritional impact of supplementary feeding program for vulnerable groups. Geneva: WHO; 1991.

6. Ismid I, Margono S. Kebersihan pribadi, sanitasi lingkungan dan status gizi anak sekolah yang menderita askariasis. Maj Parasitol Ind 1989;2:97-102.

7. Soeripto N. Dampak pembinaan air bersih, jamban keluarga dan kesehatan lingkungan terhadap prevalensi Ascaris lumbricoides di Kasongan Yogyakarta. Medika 1986;8:723-30. 


\section{Paediatrica Indonesiana}

8. Poespoprodjo JR. Infestasi cacing dan prestasi belajar anak SD di Kecamatan Ampana Kota Kabupaten Poso Sulawesi Tengah [thesis]. Yogyakarta: Department of Child Health, Medical School, Gadjah Mada Univ.; 1999.

9. Merid Y, Hegazy M, Mekete G, Teklemariam S. Intestinal helminthic infection among children at Lake Awassa Area, South Ethiopia. Ethiop J Health Dev 2001;15:31-8.

10. Rahman A. Helminthic infections of urban and rural school children in Penang Island, Malaysia: implications for control. Southeast Asian J Trop Med Public Health 1998;29:596-8.
11. Norhayati M, Zainuddin B, Mohammed CG. The prevalence of trichuris, ascaris and hookworm infection in orang asli children. Southeast Asian J Trop Med Public Health 1997;28:161-8.

12. Freij L, Meeuwisse GW, Berg NO, Wall S, GebreMedhin M, et al. Ascaris and malnutrition. A study in urban. Ethiopian children. Am J Clin Nutr 1979;32:1545-53.

13. De Silva NR, Jayapani VP, De Silva HJ. Socioeconomic and behavioral factor affecting the prevalence of geohelminths in preschool children. Southeast Asian J Trop Med Public Health 1996;27:36-42. 